Preprint version. Cite as: Van de Walle, S. (2018). Explaining Citizen Satisfaction and Dissatisfaction with Public Services. In: Ongaro, E. \& Van Thiel.S. (eds). The Palgrave Handbook of Public Administration and Management in Europe. London: Palgrave Macmillan, pp. 227-241. https://doi.org/10.1057/978-1-137-55269-3 11

\title{
Explaining citizen satisfaction and dissatisfaction with public services
}

Steven Van de Walle

\section{Abstract}

With citizens being considered customers, public administration scholars have become interested in explaining satisfaction with public services and studying the consequences of high or low satisfaction. This chapter reviews current scholarship on satisfaction with public services and in particular the mechanisms and theories to explain such satisfaction. Differences between objective performance and subjective evaluations are discussed, as well as the impact of halo effect in attitude formation and of direct user experience with service. Special attention goes to the expectancy disconfirmation model of satisfaction. The chapter does not only look at satisfaction as an attitude, but also at voice and exit behaviours from which satisfaction or dissatisfaction can be inferred. It ends by critically assessing the value of behaviours as signals of public dissatisfaction with public services. 


\section{Reforming public services - making customers happy}

Citizen dissatisfaction with public services has been a constant concern in public sector reform initiatives. Many administrative reform initiatives have explicitly made a connection between the need to reform public services, improving citizen satisfaction with public services, and maintaining or restore the public trust in government. Administrative reform in the 1980 s and 1990 s introduced the idea of treating citizens as clients and making public services more client oriented. This meant, inter alia separating the process of service delivery from the outcome, and trying to deliver the client a pleasurable service experience and turning the traditional bureaucratic state into a service delivery machine (Flynn, 2012: 156; Schedler \& Proeller, 2000; Greener, 2013). This customer orientation is reflected in the rise of numerous specific tools to help public services delivering better services, and to assist citizens and clients in making sure they are treated well (OECD 2001). Examples of such tools are for instance the widespread introduction of citizen surveys to capture what citizens want. Starting mainly in local government already in the 1970s and 1980s (Stipak, 1979), their use gradually became commonplace (Bouckaert \& Van de Walle, 2003; Roth et al. 1990). The establishment of formal complaints mechanisms and a rapid increase of ombudsman institutions are characteristic features of the 1990s. Also in the 1990s, the introduction of citizen and customer charters can be seen as a very symbolic event signalling that the public sector was increasingly taking citizen and customer satisfaction at heart. Such charters outlined the delivery standards citizen could expect from public services, and hence functioned like a contract between government and its citizens (Clark, 2000; Thomassen et al. 2014). Examples are the Citizen's Charter in the UK in 1991, The French Charte des Services Public in 1992, the Charter of the User of Public Services in Belgium, 
introduced in 1992/1993 (Van de Walle et al. 2005) and many other examples elsewhere in Europe. These general charters have been translated into operational service-specific charters, but most have since disappeared. The rise of e-government in the late 1990s not only meant attempts were made to make public services more accessible, but it also meant that governments started thinking of public service encounters as clustered around certain life-events such as birth, marriage, buying a house etc. A shift took place from an institutioncentric, supply-driven public sector to one that was citizen-centered and demand-driven. Many of the customer-oriented innovations introduced during the 1990s have endured and become commonplace, whereas others were temporary attempts to install a belief and practice that citizens can and should be treated as customers.

A further transformation started in the 1990s and continues to be at the core of public service reform. Where initial changes in the 1980s and 1990s were about treating citizens as customers, reforms in the late 1990s and 2000s started to speak about citizens not as mere customers but as true consumers of public services (Clarke et al., 2007; Newman, 2013) consumers on a public service market. Whereas earlier reforms had still focused on how public services were to be delivered by government, with an aim to become more customer oriented, this new wave of reforms focused on what services are to be delivered, with a wider aim of aligning supply of services with consumer demands (Ferlie et al., 1996; Hammerschmid et al., 2016). This trend went hand in hand with further liberalisation of public services and the introduction of competition and wider choice for citizens following the break-up of public monopolies (Le Grand, 2009). This had already started in utility sectors such water, electricity, and gas, and in telephony, but soon was expanded to other domains such as health or employment services. This meant full standardisation of public services was partly abandoned, because standardisation was considered detrimental to 
customers' satisfaction. Personal choice between competing providers and first steps towards personalisation of service delivery within the public sector are the dominant features of this new wave of reforms (Needham, 2011; Simmons, 2009).

In public administration scholarship, at the same time, debates on whether citizens can be considered customers, let alone consumers, proliferated. Such scholarship has been partly analytical - discussing the different roles citizens can take and describing general trends (Aberbach and Christensen, 2005; Ryan, 2001; Fountain, 2001), as well as critical - and highlighting the wider democratic implications of such a transition (Jung, 2010; Needham, 2006). Empirical work focusing on the first transformation (how services are provided) has been mainly descriptive and case-analytical (see, e.g., Brewer, 2007), whereas the second transformation has given rise to more in-depth empirical work on consumer choice (Brown, 2007; Jilke et al. 2015) and whether this has increased public satisfaction. There is also a growing literature on how service satisfaction may or may not ultimately have an effect on citizens' trust in the state, both conceptually (Van de Walle \& Bouckaert, 2003), and empirically (Christensen \& Lægreid, 2005; Vigoda-Gadot, 2007) but the current chapter will limit itself to service satisfaction.

This chapter looks at satisfaction and dissatisfaction with public services. It first deals with satisfaction and dissatisfaction as an attitude and more in particular discusses various mechanisms and theories to explain such satisfaction. A second part focuses on citizen may act in response to dissatisfaction with public services. It is argued that not just attitudes but also behaviours can be studied as indicators of satisfaction with public services. Some caveats about behaviours are then added, and the conclusion discusses challenges for scholarship on citizen satisfaction with public services. 


\section{Satisfaction with public services - mechanisms}

Though intuitively appealing, satisfaction with public services is a complex phenomenon, combining expectations, experiences, and prior attitudes. Reported satisfaction should not just be seen as direct reflection of experienced service quality, but it may also relate to or emanate from broader attitudes to government, such as trust in government. It is also important to remind that people who have not experienced services also have opinions about that service and that general opinions differ from more specific ones.

\section{Subjective and objective assessments of public services}

Subjective assessments, such as satisfaction, of a public service, do not necessarily reflect objective features or performance of that service (Van Ryzin, 2004; 2008), and satisfaction ratings are influenced by factors other than service quality (Van Ryzin and Immerwahr 2004; Orr and West 2007). This means improvements in service quality will not always be reflected in higher satisfaction (Stipak, 1979; Kelly and Swindell, 2002). Recent experimental work in public administration has shown that satisfaction judgements are not 'consistently related to performance' (Andersen and Hjortskov, 2015: 1) and are prone to cognitive biases, especially when it concerns more abstract services.

Subjective assessments are aggregate judgements of both the experienced service process (was the public servant accommodating, courteous etc.) and the service outcome (did I get what I wanted, or what I was entitled to). Detailed satisfaction measurements can disentangle these, yet in snap judgements, both are generally mixed. A particular finding in the literature is that depending on the outcomes they produce, different services tend to receive different baseline satisfaction ratings. It has been suggested that this is related to the sympathy citizens have for that service. A comparative study of outcomes of satisfaction 
surveys in US local governments for instance found that certain types of services consistently receive better ratings - fire departments do better than road repair services (Miller and Miller, 19991). In general, service satisfaction also depends on service characteristics, such as the directness of contact and the heterogeneity of the services offered (Das et al., 1995; Roth et al. 1990). This shows it can be risky to treat satisfaction scores in a survey as absolute, decontextualized scores.

Satisfaction depends on far more than service performance (Kelly, 2005). Still, subjective assessments are useful, because they provide policy makers and managers with aggregate judgements indicating that something may be wrong. One such thing could be a failure to deliver the kind of service people want, or the organization's focus on service quality aspects users do not find very important.

\section{Role of expectancy-disconfirmation in satisfaction}

A dominant model that has been used for a very long time in the service management literature (Anderson, 1973; Oliver, 1977; 1980), and that has in recent years also been adopted by (European) public management scholars (see, e.g., James, 2009, Morgeson, 2012; Poister \& Thomas, 2011) is the expectancy-disinformation model (EDM) of satisfaction. It posits that satisfaction can only be interpreted in conjunction with knowledge about prior expectations. These expectations are predictions of future performance, or an anticipation of what will follow, that exist prior to the service experienced. Perceived service performance is then evaluated in comparison to the original expectations, leading to a confirmation or disconfirmation of the expectations, which influences satisfaction. Citizens approaching public services with very high expectations are likely to be less satisfied than people who do not have such high expectations. For the former, expectations are 
disconfirmed by actual experience, whereas for the latter, the service experience exceeds expectations.

Many current studies in public administration rely on expectation disconfirmation as a model for explaining high or low satisfaction, and have mainly been interested in how objective service-related factors influence satisfaction (see, e.g. Van Ryzin, 2006; James, 2009; Morgeson, 2012). An important concern however has been the measurement of expectations, which was in early studies done using the same instrument as the satisfaction measurement, obviously biasing the measurement. There are also doubts whether citizens have clear expectations prior to the service encounter. One recent way around this problem is through manipulating prior expectations experimentally (Van Ryzin, 2013; James, 2014) to see how expectation management may influence satisfaction. This makes the test of the EDM model more robust, yet does move the measurement of satisfaction away from real public service encounters to the lab (see also the chapter on behavioural public administration in this volume).

If expectations, and not experienced service performance, are the key driver of satisfaction, this has implications for service delivery, and suggests that management of expectations is crucial. Expectations are probably not stable, and may be different between different groups of the population. Citizen expectations of public services have risen in recent decades. First of all, there has been a rise of the critical citizens (Norris, 1999) who have less deference to authority and hence are more critical about what they actually receive from public services. Secondly, boundaries between the public and the private sector increasingly become blurred, making it more straightforward for citizens to directly compare their experiences with public organisations to those with private sector organisations. Private 
service innovations and exposure to new practices in e.g. electronic service delivery shapes expectations towards public services. Third, service delivery in the public sector has also become large-scale and anonymous, rather than based on personal interactions. One implication could be that users become less tolerant to service failures when this human factor is absent, though complaint rates in electronic and traditional encounters appear not to differ (Snellman \& Vihtkari 2003). Finally, citizens have been stimulated to think and behave as public service customers. This means they may have started to approach public services mainly with their own individualistic demands and needs in mind, trying to get as much out of them as possible. This phenomenon has for instance been described in service interactions in social services where social workers see themselves faced with very demanding clients, who know very well what their rights are and how the game works (see Goodsell's 1981 discussion on belligerent citizens). Thinking of oneself as a customer may be particularly present in situations where citizens directly pay for the provision of a public service.

\section{Halo effects in public service satisfaction}

A recurrent finding in the public satisfaction literature is that citizens tend to value specific public services much higher than public services in general or the public sector as a whole, and that their general trust in government is generally lower than their satisfaction with public services (Grunow, 1981; Goodsell, 1994; Kelly and Swindell, 2003; Ringeling, 2004). Citizens hold certain predispositions towards the public sector (Kampen et al. 2006), or even stereotypical attitudes (Van de Walle, 2004). When not explicitly asked to think about a very specific public service organisation or experience, these more general attitudes play a stronger role. This is what scholars have called a halo effect, whereby an overall impression biases assessments of more specific traits. For public service organisations this may mean 
lower overall satisfaction because the organisation is perceived to be a part of the public sector (Van Slyke \& Roch, 2004; Marvel, 2016)

In satisfaction surveys, priming satisfaction ratings of specific services by first asking about the general attitude towards public services, can lead to considerably lower satisfaction ratings (Benton and Daly, 1991). This changes the saliency of the more general public service attitude (or even stereotype), and leads to a very different process of attitude formation because they tap into a different belief system, one that is much further removed from their actual experience with concrete public services (Van de Walle and Van Ryzin, 2011).

\section{The role of direct experience in in satisfaction (users and non-users)}

A final mechanism that tends to be present in satisfaction ratings is that users of public service often have a different opinion than non-users. That in itself is not surprising, because the former have first-hand evidence. What is more surprising, and perhaps even worrying when satisfaction scores are used in decision making is that also non-users, who do not have direct experience, also tend to have an opinion about public services.

Direct experience with a public service has two different types of effects on service satisfaction. First, having had direct experience makes the formation of a satisfaction judgement more informed overall. Second, direct experience means that people, in the process of forming a judgement on the service may take a different set of factors related to the service experience into account, because they are more familiar with the service (McGill and lacobucci, 1992). This means that experience does not just influence whether or not someone is satisfied, but it also appears to be related to the extremeness of either positive or negative opinions (Roth et al., 1990; Das et al., 1995). These effects of direct experience relate to the halo effect discussed in the previous section. When citizens have experienced 
services recently, their evaluations tend to be closer to the actual experience and further removed from stereotypes (Katz et al., 1977).

A further factor to take into account when looking at the role of use and experience on service satisfaction is that users and non-users of services tend to have different characteristics. Certain types of public services are typically used by certain types of citizens and socio-economic classes. Many government services are universal in nature, whereas others address specific groups of people. Many public services are typically more frequently used by middle- and upper classes (museums, universities), whereas others tend to attract a very different public (youth care, unemployment departments). Different needs is an explanation, but also factors such as political efficacy and participation influence actual service use especially for services where most use is citizen-initiated (Serra, 1995). Obviously, there are also different degrees in the extent to which citizens are forced to use a public service. Some services are entirely voluntary (e.g. museums) whereas others have clients that are certainly not using the service out of their own free will (e.g. prisons). Some services are difficult to escape (public roads), or compulsory (taxes), whereas for others, clients have a choice (using public transport or not).

\section{Dissatisfaction and citizens' reactions to service failure}

For scholars, satisfaction and dissatisfaction are not just interesting as attitudes. Dissatisfaction and satisfaction become highly relevant when they translate into behaviours, when stated preferences are translated into revealed preferences (Van de Walle, 2016). Traditionally, PA scholars and political scientists have had a lot of attention for political voice 
- citizens reacting to service delivery and its defects through political action: asking politicians to intervene and to speed up or facilitate service delivery (clientelism), voting for political leaders who promise to make public services more efficient to clean up the bureaucracy, or by organising themselves to protect against poorly performing services. When public services are under direct political control and sometimes even politicised, political action is often citizens' only way to intervene. If such political action fails, citizens have very little legal means to react, but can still resort to aggression, bribing, or calling in personal favours. Or they can choose to stay away, which means creating their own alternatives (e.g. taking the car rather than public transport, home-schooling their children when schools fail), being bereft from various benefits, or moving into illegality.

The combined trends of citizens being treated as customers and marketization of public services expanded citizens' ways to respond to failing services. Not only do they have formal complaint mechanisms at their disposal, and are able to complain about services just as they would when interacting with private providers, but they now can also increasingly act as consumers and vote with their feet (Tummers et al., 2013). Such voice and choice signals can be powerful reflections of public satisfaction with government services, or signal profound distrust in government. The dominant approach to studying reactions to failing services is that developed by Albert O. Hirschman (1970), after experiencing the dismal performance of the Nigerian railways. His exit-voice-loyalty framework has proved to be a very useful way of categorising behavioural reactions, and it is increasingly being tested in a public service context (Dowding \& John, 2012).

Voice means that citizens express their satisfaction with public services through speaking out. They can do so in different ways. They can complain directly to a service provider 
during the service interaction, or they can submit a complaint afterwards. Voice can also be expressed through media and, nowadays, social media. Voice can be moderate and hesitating, but it can also border on verbal aggression toward the service provider. Voice can be a mere complaint about a public service, but complaints may also come with an attribution of responsibility or blame (Hood, 2010; James et al., 2016). It can be addressed at those delivering the service, those managing it, or at those politically responsible for the public service. Voice can be an individual act, but it can also be organised collectively, when dissatisfied public service users unite and submit a petition or a joint complaint, set up an action committee to get their message across, or collectively launch a class action suit.

Different strands of public management research have studied voice. More applied scholars have looked at complaints and complaint mechanisms. Street-level bureaucracy scholars are interested in how users and providers interact, also when things do not go as planned. Political scientists have been interested in political expressions of voice and collective voice (James \& John, 2007).

Voice is a direct and personal signal that signals that someone is not satisfied with public services. That makes it risky for those using voice, but at the same time it generally expresses a desire to see the service improved. Otherwise, they would probably not bother to express their voice or complain. Exit, however, means that users terminate their relationship with the service provider. When only small numbers exit, this is unlikely to have a deep impact on the public service involved. However when large numbers begin to exit, this can be a powerful signal. In the absence of choice and public service markets, exit can be a big step for users who are dissatisfied, because of a lack of alternatives. Dissatisfaction with public services may then mean giving up using a service altogether (but continuing to 
pay for them through taxes), and thus also losing the benefits use brings. It may also mean having to move to alternative providers who are for instance privately organised and charge high fees (such as moving to private health care or private schools), or alternative providers whose credentials are not generally accepted, such as for patients leaving the established medical system and moving to alternative medicine or healers (Raaphorst and Houtman, 2016). Exit following dissatisfaction with services can result in new alternatives being developed, either by other public providers, by the market, or by citizens themselves, who set up their own alternatives alongside the established public services (Gofen 2012). It can however also result in non-take-up of services because they are seen to be failing (Warin, 2003). This is a phenomenon that is not problematic for those who can afford the alternative, but it is problematic when it affects those who lack the self-efficacy to use public services they are entitled to or in need of, and cannot afford the private market.

\section{The pitfalls of behaviour as signals of service (dis)satisfaction}

The downside of studying behaviour is that one can only observe them when they occur, and that absence of behaviour normally associated with dissatisfaction does not mean that dissatisfaction is absent. At the same time presence of satisfaction or dissatisfaction signals does not mean that satisfaction or dissatisfaction are substantial or genuine either.

Acting on one's dissatisfaction may come at great cost. Users have invested in service relationships, and abandonment means writing off these investments and having to learn new routines or jargon. Acting on one's dissatisfaction does not only come with material costs (sunk costs), but also with substantial emotional and cognitive costs. Recent experimental research has for instance shown that searching for and picking an alternative provider after being dissatisfied can be hindered by a cognitive choice overload (Jilke et al., 
2015). Also, setting up one's own alternatives, as described earlier, can be very time consuming, and not always worth the effort if the expected future frequency of use is low, or when a service is not very important to the user.

Complaining about a public service can be quite risky for a user. Complaints, especially direct personal ones rather than impersonal complaints through an abstract complaint form may jeopardise the relationship between user and suppliers, especially when the service interaction is a very intimate or emotional one (Guy, Newman \& Mastracci, 2015). Think about social workers and their clients, prison guards and inmates, or about situations where public services are coproduced. Complaining may also jeopardise service outcomes, when for instance the public official dealing with the case decides to go by the book and refrain from using discretion, decides to go very slow, or to directly sabotage the service process by e.g. losing a file.

Expressing dissatisfaction can also be a strategy for users hoping to receive better or faster treatment, or hoping to be considered for a service when in fact they are not entitled to such services. Citizens who complain or who are otherwise vocal can make life very stressful for public officials (Jin \& Guy, 2009). Bowing to their demands is then an easy way out.

Behaviour signalling satisfaction also has its interpretation pitfalls. In the private services literature, positive word of mouth or recommending a service, and return custom are generally used as indicators of service quality and user satisfaction (Anderson, 1998). For the former, there are probably quite high thresholds for speaking positively about a public services let alone recommending it. This would mean going against established opinions that public services do not perform well, and where stories about bad government performance create social status (Harris et al., 2016). Return custom is also probably not a 
very good satisfaction indicator, because of the forced nature of many public services delivered by a monopoly supplier, but also because of the frequency of use of many services. Some services are used very infrequently (once or a couple of times in a lifetime), or very frequently, making it difficult not to be a return customer due to a lack of suitable alternatives.

\section{Conclusion - studying satisfaction with public services}

Satisfaction with public services can be studied at different levels. At its most basic level, one can look at the operational qualities of a public service to see how service quality translates into service satisfaction. This reduces satisfaction to a mechanical process operating at the interface between services and customers. A focus on this basic level allows scholars and practitioners to use insights from the private service management literature and service consultancy in order to identify drivers of satisfaction and dissatisfaction and segmentation in the user or customer base in the public domain. One can also broaden one's take on service satisfaction by incorporating prior expectations and views about the service to see how these influence later satisfaction. Broadening the approach to service satisfaction means not taking the service being delivered at face value, but questioning the type of service being delivered, and whether dissatisfaction is merely the result of objective service quality and prior expectations, or whether it stems from dissatisfaction with the type of services being delivered. Still one step further, one can look at various customer behaviours following satisfaction and dissatisfaction, and the subsequent effect of such individual or collective behaviours on the public service involved or even the entire public service system within which that service operates. One can also explore whether satisfaction and dissatisfaction with services spill over into attitudes toward the entire 
system of government, such as trust in government, or satisfaction with the way government works.

An example can illustrate these different approaches. One can study and try to explain satisfaction with a public postal service by studying whether citizens are more satisfied with the service when mail is delivered on time, and which segments of the population are more or less satisfied, triggered by which service quality criteria. One can also relate satisfaction to prior expectations about the postal service, and more specifically existing stereotypes about the postal service (see, e.g. the recent work by Marvel, 2016). One step further one can investigate whether traditional postal services and post offices is what citizens are interested in, or whether they are more interested in parcel deliveries at the time they want. Finally, one can look at the behaviours of users, e.g. when they express their dissatisfaction in encounters with the mailman, blame their politicians for a malfunctioning mail service, or defect from the public postal service to private parcel companies, and how such dissatisfaction changes the entire postal market. Satisfaction with public services can be the end point of research - the result of a service encounter, but it can also be the beginning of research, by looking at the consequences of such satisfaction and dissatisfaction.

Finally, some conclusions can be drawn with regard to the current state of research in Europe. Measuring citizen satisfaction through customer surveys has become common for most European public administrations, especially in agencies that perform bulk operations for millions of citizens (Hammerschmid et al., 2016). In addition, public organisations organise large-scale surveys on public opinion, also including satisfaction with public services such as the police, public transport, or the education system. More and more of this 
data is also being used by scholars, who in addition also collect their own data. Satisfaction data is especially available for social service organisations and utilities (see, e.g., Clifton et al., 2014; Jilke \& Van de Walle, 2013). Whereas originally scholarly attention mainly went to measuring satisfaction, and explaining this satisfaction by referring to service and customer characteristics, current research also looks at how satisfaction attitudes are formed, and has also integrated expectations in its thinking (James, 2009; Morgeson, 2012). Experimental methods are increasingly being used (Andersen and Hjortskov, 2015; James, 2014), while surveys remain the main research instruments (Ferrari \& Manzi, 2014; Overman, 2016). Qualitative research is largely absent, though it is used more often in health service settings. Most survey-based work consists of traditional satisfaction surveys, whereas other approaches such as willingness to pay surveys, demand surveys, and budget surveys are almost exclusively used by economists studying public services (Schläpfer, 2015). The latter approaches though, which link evaluation of services to how they are paid for, could prove to be very useful in a time when more and more public services find themselves in a market environment. The strong focus of PA satisfaction scholarship on expectations and attitude formation means that very few scholars still work on service quality and operational characteristics of the service as determinants of service quality, and that alternative approaches to satisfaction such as need fulfilment are largely absent (Oliver, 2015). Incorporating both mainstream and advanced insights on customer satisfaction from the private services literature into public administration research will therefore be a straightforward way of expanding research into public service satisfaction. 


\section{References}

Aberbach, J. D., \& Christensen, T. (2005). Citizens and consumers: An NPM dilemma. Public Management Review, 7(2): 225-246.

Anderson, E. W. (1998). Customer satisfaction and word of mouth. Journal of Service Research, 1(1): 5-17.

Andersen, S.C., \& Hjortskov, M. (2015). Cognitive biases in performance evaluations. Journal of Public Administration Research and Theory, online first.

Anderson, R.E. (1973). Consumer dissatisfaction: the effect of disconfirmed expectancy on perceived product performance. Journal of Marketing Research, 10(1): 38-44.

Benton, J.E., \& Daly, J.L. (1991). A question order effect in a local government survey. The Public Opinion Quarterly, 55(4): 640-2.

Bouckaert, G., \& Van de Walle, S. (2003). Comparing measures of citizen trust and user satisfaction as indicators of 'good governance': Difficulties in linking trust and satisfaction indicators. International Review of Administrative Sciences, 69(3): 329-44.

Brewer, B. (2007). Citizen or customer? Complaints handling in the public sector. International Review of Administrative Sciences, 73(4): 549-56.

Brown, T. (2007). Coercion versus choice: Citizen evaluations of public service quality across methods of consumption. Public Administration Review, 67(3): 559-72.

Christensen, T., \& Lægreid, P. (2005). Trust in government: The relative importance of service satisfaction, political factors, and demography. Public Performance \& Management Review, 28(4), 487-511. 
Clark, D. (2000). Citizens, charters and public service in Britain and France. Government and Opposition, 35(2): 152-169.

Clarke, J., J. Newman, N. Smith, L. Westmarland, \& Vidler, E. (2007). Creating citizen consumers: Changing publics \& changing public services. London: Sage.

Clifton, J., Díaz-Fuentes, D., \& Fernández-Gutiérrez, M. (2014). The impact of socioeconomic background on satisfaction: evidence for policy-makers. Journal of Regulatory Economics, 46(2), 183-206.

Das, H., Das, M. \& Mckenzie, F. (1995). Assessing the "will of the people": an investigation into town delivery satisfaction. Canadian Public Administration, 38, (1): 77-93.

Dowding, K. and John, P. (2012). Exits, voices and social investment: Citizens' reaction to public services. Cambridge: Cambridge University Press.

Ferlie, E., L. Ashburner, L. Fitzgerald, \& Pettigrew, A. (1996). The new public management in action. Oxford: Oxford University Press.

Ferrari, P.A. \& Manzi, G. (2014). Citizens evaluate public services: a critical overview of statistical methods for analysing user satisfaction. Journal of Economic Policy Reform, 17(3): 236-252.

Flynn, N. (2012). Public sector management. London: Sage.

Fountain, J.E. (2001). Paradoxes of public sector customer service. Governance, 14(1): 5573.

Gofen, A. (2012). Entrepreneurial exit response to dissatisfaction with public services. Public Administration, 90(4): 1088-106. 
Goodsell, C. T. (1981). Looking once again at human service bureaucracy. The Journal of Politics, 43(3), 763-778.

Goodsell, C.T. (1994). The case for bureaucracy: a public administration polemic. 3rd ed. Chatham: Chatham House Publishers Inc.

Greener, I. (2013). Public management. Houndmills: Palgrave Macmillan.

Grunow, D. (1981). Client-centered research in Europe. In Goodsell, C. T. (ed.). The public encounter: where state and citizen meet, Bloomington: Indiana University Press, pp. 223-41.

Guy, M.E., Newman, M.A., \& Mastracci,S.H. (2015). Emotional labor. Putting the service in public service. London: Routledge.

Hammerschmid, G., Van de Walle, S., Andrews, R. \& Bezes, P. (eds)(2016). Public administration reforms in Europe: the view from the top. Cheltenham: Edward Elgar.

Harris, L.C., Fisk, R.P., \& Sysalova, H. (2016). Exposing Pinocchio customers: investigating exaggerated service stories. Journal of Service Management, 27(2): 63-90.

Hirschman, A.O. (1970). Exit, voice, and loyalty: response to decline in firms, organizations and states. Cambridge, MA: Harvard University Press.

Hood, C. (2010). The blame game: spin, bureaucracy, and self-preservation in government, Princeton: Princeton University Press.

James, O. (2009). Evaluating the expectations disconfirmation and expectations anchoring approaches to citizen satisfaction with local public services. Journal of Public Administration Research and Theory, 19(1): 107-23. 
James, O., Jilke, S., Petersen, C., \& Van de Walle, S. (2016). Citizens' blame of politicians for public service failure: experimental evidence about blame reduction through delegation and contracting. Public Administration Review, 76(1): 83-93.

James, O., \& Moseley, A. (2014). Does performance information about public services affect citizens' perceptions, satisfaction, and voice behaviour? Field experiments with absolute and relative performance information. Public Administration, 92(2): 493-511.

James, O., \& John, P. (2007). Public management at the ballot box: Performance information and electoral support for incumbent English local governments. Journal of Public Administration Research and Theory, 17(4): 567-80.

Jin, M. H., \& Guy, M. E. (2009). How emotional labor influences worker pride, job satisfaction, and burnout: an examination of consumer complaint workers. Public Performance \& Management Review, 33(1), 88-105.

Jilke, S., \& Van de Walle, S. (2013). Two track public services? Citizens' voice behaviour towards liberalized services in the EU15. Public Management Review, 15(4), 465-476.

Jilke, S., Van Ryzin, G., \& Van de Walle, S. (2015). Responses to decline in marketized public services: An experimental evaluation of choice-overload. Journal of Public Administration Research and Theory, early view, DOI 10.1093/jopart/muv021.

Jung, T. (2010). Citizens, co-producers, customers, clients, captives? A critical review of consumerism and public services. Public Management Review, 12(3): 439-446.

Kampen, J. K., Van de Walle, S., \& Bouckaert, G. (2006). Assessing the relation between satisfaction with public service delivery and trust in government: The impact of the 
predisposition of citizens toward government on evaluations of its performance. Public Performance and Management Review, 29 (4): 387-404.

Katz, D., Gutek, B.A., Kahn, R L., \& Barton, E. (1977). Bureaucratic encounters: a pilot study in the evaluation of government services. Ann Arbor: Institute for social research.

Kelly, J.M. (2005). The dilemma of the unsatisfied customer in a market model of public administration. Public Administration Review, 65(1): 76-84.

Kelly, J.M., \& Swindell, D. (2002). A multi-indicator approach to municipal service evaluation: correlating performance measurement and citizen satisfaction across jurisdictions. Public Administration Review, 62 (5): 610-21.

Kelly, J.M., \& Swindell, D. (2003). The case for the inexperienced user: rethinking filter questions in citizen satisfaction surveys. American Review of Public Administration, 33(1): 91-108.

Le Grand, J. (2009). The other invisible hand: Delivering public services through choice and competition. Princeton: Princeton University Press.

Marvel, J.D. (2016). Unconscious bias in citizens' evaluations of public sector performance. Journal of Public Administration Research and Theory, 26(1): 143-58.

McGill, A.L., \& lacobucci, D. (1992). The role of post-experience comparison standards in the evaluation of unfamiliar services. In: John F. Sherry, Jr. and Brian Sternthal, Advances in consumer research, vol. 19, pp. 570-579. Provo, UT: Association for Consumer Research.

Miller, T.I., \& Miller, M.A. (1991). Standards of excellence: US residents' evaluations of local government services. Public Administration Review, 51(6): 503-13. 
Morgeson, F.V. (2012). Expectations, disconfirmation, and citizen satisfaction with the U.S. federal government: Testing and expanding the model. Journal of Public Administration Research and Theory, 23(2): 289-305.

Needham, C. (2006). Customer care and the public service ethos. Public Administration, 84(4): 845-60.

Needham, C. (2011). Personalising public services: Understanding the personalisation narrative. Bristol: Policy Press.

Newman, J. (2011). Serving the public? Users, consumers and the limits of NPM. In: Tom Christensen and Per Lægreid (eds), The Ashgate research companion to new public management, pp. 349-359. Farnham: Ashgate.

Norris, P. (ed.)(1999). Critical citizens: global support for democratic governance. Oxford: Oxford University Press.

OECD (2001). Citizens as partners: OECD handbook on information, consultation and public participation in policy-making. Paris: OECD

Oliver R.L. (1977). Effect of expectation and disconfirmation on postexposure product evaluations - an alternative interpretation. Journal of Applied Psychology, 62(4): 480-86.

Oliver R.L. (1980). A cognitive model of the antecedents and consequences of satisfaction decisions. Journal of Marketing Research, 17(4): 460-69.

Oliver, R.L. (2015). Satisfaction. A behavioral perspective on the consumer (2nd ed.). Abingdon: Routledge. 
Orr, M., \& West, D.M. (2007). Citizen evaluations of local police: personal experience or symbolic attitudes? Administration \& Society, 38(6): 649-68.

Overman, S. (2016), Autonomous agencies, happy citizens? Challenging the satisfaction claim. Governance. doi: 10.1111/gove.12207.

Poister, T.H., \& Thomas, J.C. (2011). The effect of expectations and expectancy confirmation/disconfirmation on motorists' satisfaction with State highways. Journal of Public Administration Research and Theory, 21 (4): 601-617.

Raaphorst, N. \& Houtman, D. (2016). A necessary evil that does not "really" cure disease: the domestication of biomedicine by Dutch holistic general practitioners. Health, 20(3): 24257.

Ringeling, A. (2004). Het imago van de overheid. 's Gravenhage: Elsevier Overheid Roth, V.J., Bozinoff, L., \& Maclntosh, P. (1990). Public opinion and the measurement of consumer satisfaction with government services. Canadian Public Administration, 33(4): 571-83.

Ryan, N. (2001). Reconstructing citizens as consumers: Implications for new modes of governance. Australian Journal of Public Administration, 60(3): 104-09.

Schläpfer, F. (2015). Stated preferences for public services: A classification and survey of approaches. Journal of Economic Surveys. Early view, DOI: 10.1111/joes.12140

Serra, G. (1995). Citizen-initiated contact and satisfaction with bureaucracy: a multivariate analysis. Journal of Public Administration Research and Theory, 5(2): 175-88. 
Simmons, R. (2009). Understanding the 'differentiated consumer' in public services. In Simmons, R., Powell, M., \& Greener, I. (eds)(2009). The consumer in public services: Choice, values and difference. Bristol: Policy Press, pp. 57-76.

Snellman, K., \& Vihtkari, T. (2003). Customer complaining behaviour in technology-based service encounters. International Journal of Service Industry Management, 14(2): 217- 231.

Stipak, B. (1979). Citizen satisfaction with urban services: potential misuse as a performance indicator. Public Administration Review, 39(1): 46-52.

Thomassen, J.P., Ahaus, K., Van de Walle, S., \& Nabitz, U. (2014). An implementation framework for public service charters: results of a concept mapping study. Public Management Review, 16(2): 570-589.

Tummers, L., Jilke, S., \& Van de Walle, S. (2013). Citizens in charge? Reviewing the background and value of introducing choice and competition in public services. In Dwivedi, Y.K., Shareef, M.A., Pandey, S.K. \& Kumar, V. (eds.). Public administration reformation: market demand from public organizations. London: Routledge, pp. 24-42.

Van de Walle, S. (2004). Context-specific images of the archetypical bureaucrat: persistence and diffusion of the bureaucracy stereotype, Public Voices, 7(1): 3-12.

Van de Walle, S. (2016). When public services fail: A research agenda on public service failure. mimeo.

Van de Walle, S. \& Bouckaert, G. (2003). Public service performance and trust in government: the problem of causality.International Journal of Public Administration, 29 (8 \& 9): 891-913. 
Van de Walle, S., Thijs, N., \& Bouckaert, G. (2005). A tale of two charters: Political crisis, political realignment and administrative reform in Belgium. Public Management Review, 7(3): 367-90.

Van de Walle, S., \& Van Ryzin, G. (2011). The order of questions in a survey on citizen satisfaction with public services: Lessons from a split-ballot experiment. Public Administration, 89(4): 1436-50.

Van Ryzin, G.G. (2004). Expectations, performance and citizen satisfaction with urban services. Journal of Policy Analysis and Management, 23(3): 433-48.

Van Ryzin, G.G. (2006). Testing the expectancy disconfirmation model of citizen satisfaction with local government. Journal of Public Administration Research and Theory, 16(4): 599611.

Van Ryzin, G.G. (2008). Citizen perceptions of road smoothness: evidence from New York with implications for comparative performance measurement. International Review of Administrative Sciences, 74(4): 575-88.

Van Ryzin. G.G. (2013). An experimental test of the expectancy-disconfirmation theory of citizen satisfaction. Journal of Policy Analysis and Management, 32(3): 597-614.

Van Ryzin, G. G., Muzzio, D., Immerwahr, S., Gulick, L., \& Martinez, E. (2004). Drivers and consequences of citizen satisfaction: An application of the American customer satisfaction index model to New York City. Public Administration Review, 64(3): 331-41.

Van Slyke, D.M., \& Roch, C.H. (2004). What do they know, and whom do they hold accountable? Citizens in the government-nonprofit contracting relationship. Journal of Public Administration Research and Theory, 14(2): 191-209. 
Vigoda-Gadot, E. (2007). Citizens' perceptions of politics and ethics in public administration: A five-year national study of their relationship to satisfaction with services, trust in governance, and voice orientations. Journal of Public Administration Research and Theory, 17(2), 285-305.

Schedler, K., \& Proeller, I. (20002). New public management. Bern: Verlag Paul Haupt.

Warin, P. (2003). Mesurer le non-recours aux prestations: La recherche d'indicateurs. Recherches et Prévisions, 73(1): 90-96. 